\section{Marx on Hegel}

Critique of Hegel's "Philosophy of Right". By Karl Marx. Edited by Joseph O'Malley with an introduction and notes. Translated from the German by Annette Jolin and Joseph O'Malley. Pp. lxvii + 151. (Cambridge University: London, December 1970.) 55s; $\$ 9.50$. THOSE interested in the philosophical basis of Marx's political and social writings will find this work of value. It is a translation of Marx's critical commentary on paragraphs 261-313 of Hegel's Philosophy of Right, and is popularly referred to as Marx's Critique. It was probably written in 1843 , when Marx was 25. Although extracts of this work have previously been translated into English, Joseph O'Malley and Annette Jolin are the first to have attempted a complete translation. O'Malley has added an excellent introduction with many useful bibliographical references.

In the Critique, Marx brilliantly criticizes Hegel's attempt in the Philosophy of Right to justify the Prussian State in terms of his "Philosophy of the Absolute". Marx effectively exposes what he calls the pantheistic mystification of Hegel's method. His critical technique is based on Ludwig Feuerbach's insight that speculative philosophy, and in particular Hegelian philosophy, transposes subject and predicate so reducing man to a mere mode or predicate of the Absolute Idea, whereas he is, and ought to be, the subject. Hegel, Marx holds, uses political actuality as a mere illustration for his logic, and therefore misses its significance and leaves its contradictions unreconciled. But the task of philosophy, according to Marx, is to clarify such contradictions; and this is where his historico-genetic method comes in, for in tracing the historical development of political and social institutions their meaning becomes clear. In the Critique Marx therefore gives more than a critical analysis of Hegel's method. As the work progresses, more and more space is given to historical data and to expositions of his doctrinal attitudes, for example, on private property.

Marx accepts as true, however, the contradictions which feature in Hegel's analysis between the private, or civil, and the universal, or political, spheres. As O'Malley points out in his introduction, both Marx and Hegel are inheritors of Rousseau's problem: how is private interest to be reconciled with the general, or l'homme with le citoyen. Furthermore, Marx accepts Hegel's basic doctrine of the state as the embodiment of rational freedom. In other words, for both there is an ideal dimension to man, that of freedom, morality, social life; in short, the state. For Marx, this sets the standard by which to judge social and political institutions. The portmanteauterm that Marx uses in this connexion is one originally put forward by Feuerbach, that of the "species-being" (Gattungswesen), which Marx uses in the sense, roughly, of one who is aware of himself as a member of a species, and thus has an idea of what it means to be a human being. $\mathrm{He}$ is thus able to maintain that there is an implicit rational and ethical content in social and political life, so that philosophy in its proper role of praxis is able to find the criterion by which to judge institutions, within empirical reality.

The Critique is salutary reading for anyone who may be inclined to forget just how firmly Marx's doctrine is set within the same tradition as Hegel's. WOLfE MAYS

\section{Scales in Sea}

Sounds of Western North Atlantic Fishes: a Reference File of Biological Underwater Sounds. By Marie Poland Fish and William H. Mowbray. Pp. $x x+207$. (Johns Hopkins: Baltimore, Maryland and London, December 1970.) 119s.

SINCE at least the days of Aristotle, men have known that some fish are capable of making a noise audible in the air. In the Historia Animalium book 4, 9, Aristotle cited a number of Greek fishes which made piping sounds when captured. One described as a "sciaena", possibly the meagre Argyrosomus regius, grunted, while another, identified as the cuckoo gurnard (Aspitrigla cuculus), by D'Arcy Thompson in his translation of Aristotle, was said to make a noise like the cuckoo. Knowledge of fish noises advanced slowly, but in the nineteenth century a number of studies, notably those by Sorensen in 1895, and Dufossé in 1874, demonstrated the significance of sound production underwater and explored the anatomy of some of the better known sonic fishes. Until the beginning of the second world war most of the literature on the subject dealt with the more notable sound producers, such as the American Atlantic coast oyster toadfish (Opsanus tau), and the common failure to appreciate the level of noise in the sea gave rise to popular phrases like "the silent sea" well into the 1950s.

It was the second world war with the increasing sensitivity of underwater listening devices that focused attention on the variety of sounds underwater and the potential of several phyla of marine animals to produce noise. The majority of marine soundmakers that have been identified are fishes, and Sounds of Western North Atlantic Fishes is a collected album of fish noises. The basic research has been conducted under a contract from the US Navy, which clearly has a particular interest in the identification and physical description of underwater noises.

In this work Marie Poland Fish and William H. Mowbray present a report on the sound-making capabilities of 220 species, from 59 families of fish found on the Atlantic and Caribbean coasts of the United States. The catalogue is arranged in systematic order, under familial and scientific names. Notes on the distribution, size and biology of each species are given, together with a verbal description of the noises produced in test tanks, and occasionally, where possible, in the wild. Notes on the sonic mechanisms involved have been included. Where this atlas differs from previous work is that in addition to describing the clicks, bumps, purrs, and thumps which these fish produce, these data are reproduced in spectrogram and oscillogram form for every species described. In this way, the description of fish sounds in the area has been placed on a firm physical basis and the way is clear for comparative studies of other species, and in other oceans.

As a work of reference it is invaluable. It is not without some frivolous interest, for, as the authors point out, fish use noises for much the same reasons as landliving vertebrates. Increased loquacity in the breeding season, sounds for offence, intimidation, and warning, are observable in their vocabularies, and it can be no surprise that the authors report that an enormous jewfish (Epinephelus itajara), more than 1.8 metres in length, when prodded in its pen emitted a "tremendous boom, sometimes with two smaller grunts following". ALWYNE WHEELER

\section{Immune Responses}

Cellular Immunology. Books One and Two. By Sir Macfarlane Burnet. Pp. ix +726 . (Melbourne University : Carlton, Victoria; Cambridge University: London, 1969.) 110s.

Immunological Surveillance. By Sir Macfarlane Burnet. Pp. 280. (Pergamon: Oxford, London and New York, November 1970.) 60s.

SinCE his "retirement" Sir Macfarlane Burnet has been, if anything, more productive than in the later years of his administrative responsibility. $\mathrm{He}$ has on his own admission attempted to sit back and review the work of others, though largely against the background of the various theories he has propounded. The results are presented as a massive compendium on cellular immunology together with a briefer exposé of the possible role of immunological surveillance mechanisms active against malignant cell populations. Burnet's views are always presented in an intensely personal manner. His confidence is sometimes infective, on other occasions exasperating-rarely is the reader left unmoved.

Cellular Immunology comprises two volumes, one of which has been issued separately as Self and Non-Self. The same material is looked at first in a semi- 